
2. To: (Receiving Organization)
Facility Modifications and
Projects
5. Proj./Prog./Dept./Div.:
Spent Nuclear Fuel Project
3. From: (originating Organization)
Facility Cleanup Projects
6. Design Authority/ Design Agent/Cog. Engr.:
K. H. Bergsman

8. Originator Remarks:

Approval and Release
4. Related EDI No.:

$\mathrm{N} / \mathrm{A}$

11. Receiver Remarks: 11A. Design Baseline Document? [] Yes [X] No

10. System/Bldg./Facility:

7. Purchase Order No.:

N/A

9. Equip./Component No.:

$\mathrm{N} / \mathrm{A}$

N/A

12. Major Assm. Dwg. No.:

N/A

13. Permit/Permit Application No.: $N / A$

14. Required Response Date: N/A

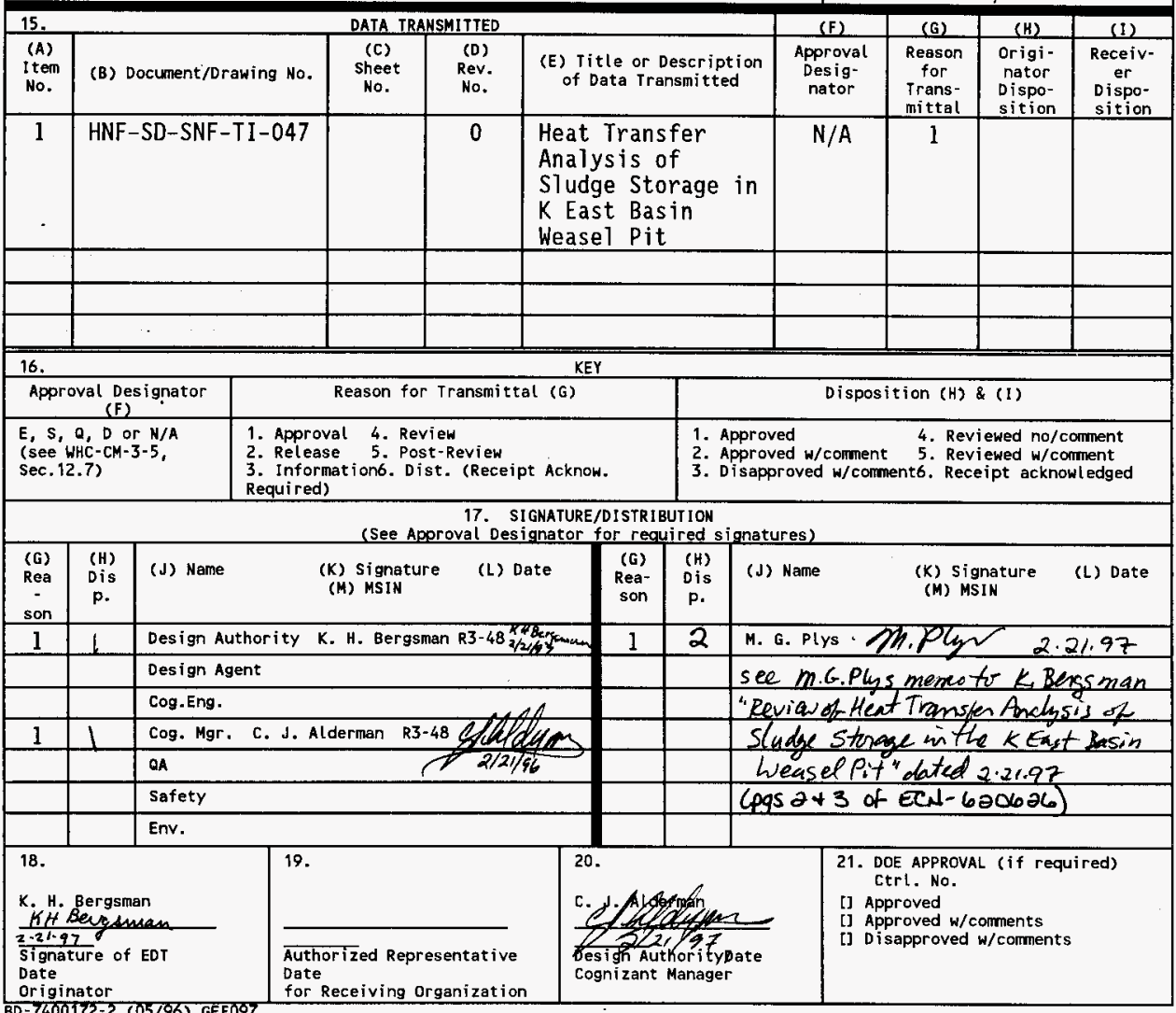


Table 1: Temperature rise calculations.

\begin{tabular}{|c|c|c|c|c|c|c|c|c|c|c|}
\hline$Q$ & $\begin{array}{l}\text { Sludge } \\
\text { Density }\end{array}$ & $\begin{array}{c}\text { Q"' } \\
\text { Decay }\end{array}$ & RM & $u$ & $\begin{array}{l}\text { Eff. } \\
\text { Temp. }\end{array}$ & $\begin{array}{c}\text { Q"' } \\
\text { OXID }\end{array}$ & $\begin{array}{c}Q^{m} \\
\text { TOTAL }\end{array}$ & k & L & $\begin{array}{c}\text { Temp } \\
\text { Rise }\end{array}$ \\
\hline KW/kg & $\mathrm{kg} / \mathrm{m}^{\wedge} 3$ & $W / m^{\wedge} \mathbf{3}$ & & & K & $W / m^{\wedge} 3$ & $W / m^{\wedge} 3$ & $W / m-k$ & $\mathrm{~m}$ & K \\
\hline $7.30 \mathrm{E}-05$ & 2300 & 127.604 & 0.82 & 0.76 & 310 & 42.1 & 169.7 & 0.6 & 0.49 & 33.9 \\
\hline $7.30 \mathrm{E}-05$ & 2300 & 127.604 & 0.82 & 0.76 & 312 & 48.6 & 176.2 & 0.6 & 0.49 & 35.2 \\
\hline 7.30E-05 & 2300 & 127.604 & 0.82 & 0.76 & 314 & 55.9 & 183.5 & 0.6 & 0.49 & 36.7 \\
\hline $7.30 E-05$ & 2300 & 127.604 & 0.82 & 0.76 & 316 & 64.4 & 192.0 & 0.6 & 0.49 & 38.4 \\
\hline 7.30E-05 & 2300 & 127.604 & 0.82 & 0.76 & 318 & 73.9 & 201.5 & 0.6 & 0.49 & 40.3 \\
\hline
\end{tabular}

The actual temperature rise across the third layer sludge is about $42 \mathrm{~K}$, which is in fair agreement with results shown in Table 1.

Total volumetric heat generation for the subject analysis was found from the temperature distribution shown in Figure 1. The temperature gradient at the top of the sludge is known to be $154.24 \mathrm{~K} / \mathrm{m}$. Heat flux at the top of the sludge is then:

$$
q^{\prime \prime}=-k d T / d x=0.6(154.24)=92.5 \mathrm{~W} / \mathrm{m}^{2}
$$

Volumetric heat generation is then:

$$
Q^{\prime \prime}=q^{\prime \prime} / L=189 \mathrm{~W} / \mathrm{m}^{3}
$$

From Table 1, a total volumetric heat generation rate of $189 \mathrm{~W} / \mathrm{m} 3$ gives a temperature rise of about $38 \mathrm{~K}$, which agrees reasonably well with the $42 \mathrm{~K}$ value calculated for the subject analysis, and demonstrates that the temperature distribution in Figure 1 of the subject analysis is correct within stated assumptions. Disagreement between the hand-calculation and the subject analysis can be attributed to neglect of the first and second layers in the hand-calculation.

\section{COMMENTS AND SUGGESTIONS}

The text on page A-10 is inconsistent. Decay heat is listed as $0.073 \mathrm{~kW} / \mathrm{MT} U$ and from the SNF Project Technical Databook, WHC-SD-SNF-TI-015, this appears to be correct. But the uranium content of wet sludge should be used in calculations by considering the sludge water fraction and the actual $U$ content of the particles. This means that calculations are conservative because decay power is actually lower. The value should be checked and a wet basis value (kW/MT sludge) should be derived. On the same page, a reference for [Willis, 1995] cannot be found in Section 6.0.

A conservatism in the subject analysis is the assumption that heat conduction is one-dimensional and upward only. Further analysis might credit heat conduction downward through the weasel pit concrete floor, and sideward through weasel pit concrete walls. This introduces a two-dimensional (or perhaps three-dimensional) conduction problem, but increases the heat transfer area available to remove heat from the sludge.

A summary table of important parameters and their sources would be useful, including conversion to a consistent set of units so that equations are clearer. 


\section{Heat Transfer Analysis of Sludge Storage in the K East Basin Weasel Pit}

K. H. Bergsman/M. J. Packer

Duke Engineering \& Services Hanford, Inc., Richland, WA 99352

U.S. Department of Energy Contract DE-AC06-96RL13200
EDT/ECN: 620626
UC: 600
Org Code: 2T240
Charge Code: LD143
B\&R Code: EW3135040
Total Pages: 33

Key Words: FDC, K East Basin, Weasel Pit, Sludge Storage, IWTS

Abstract: This document estimates the temperature of the sludge inventory projected to be stored in the $K$ East Basin Weasel Pit during the Spent Nuclear Fuel Project. Hydrogen generation rates are also estimated. Since many of the needed sludge properties are not well known, the analysis considered a range values to show the sensitivity of the results.

TRADEMARK DISCLAIMER. Reference herein to any specific commercial product, process, or service by trade name, trademark, manufacturer, or otherwise, does not necessarily constitute or imply its endorsement, recommendation, or favoring by the United States Government or any agency thereof or its contractors or subcontractors.

Printed in the United States of America. To obtain copies of this document, contact: Document Control Services, P.O. Box 950, Mailstop H6-08, Richland HA 99352, Phone (509) 372-2420; Fax (509) 376-4989.
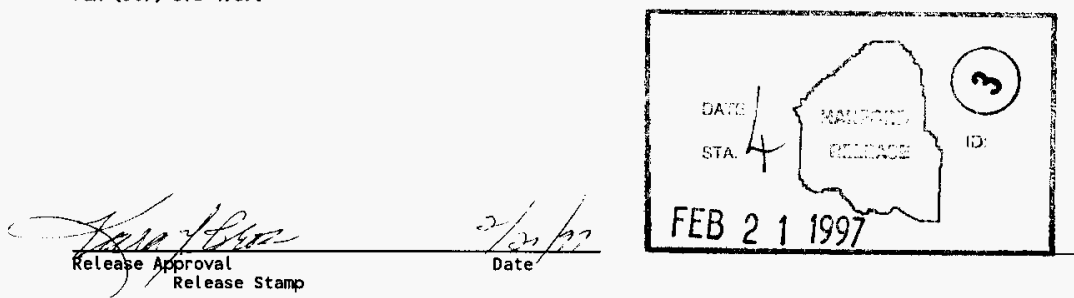

\section{Approved for Public Release}




\section{HNF-SD-SNF-TI-047, Rev 0 \\ Table of Contents}

1.0 Introduction ... . . . . . . . . . . . . . . . . . 1

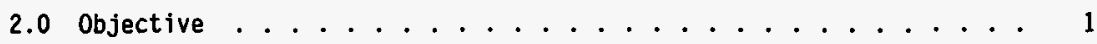

3.0 Conclusions and Recommendations ................. . 1

4.0 Method of Analysis . . . . . . . . . . . . . . . . . 3

4.1 Sludge Stored in the Weasel Pit .............. 3

4.2 Simplifications to Heat Transfer Mode1 . . . . . . . . . . . . 4

4.3 Uncertainty in Heat Transfer Input Data . . . . . . . . . . 4

5.0 Summary of Results . . . . . . . . . . . . . . . . . . 7

6.0 References......................... 14 
HNF-SD-SNF-TI-047, Rev 0

This page intentially left blank 
Heat Transfer Analysis of Sludge Storage in the K East Basin Weasel Pit

\subsection{Introduction}

As currently planned for the K East (KE) Basin, fuel and non-fuel pieces up to 1/4-inch in diameter will be received from the Fuel Retrieval System (FRS) and Sludge Retrieval System sub-projects. The floor sludge received from the Sludge Retrieval sub-project will be predominantly non-uranium (i.e., dirt, sand, concrete bits, iron oxide, aluminum oxide, etc.) although it will contain some uranium in various chemical forms. The sludge received from the FRS sub-project will have a much higher fraction of uranium as metal and compounds. Current plans are to store these materials in the Weasel Pit (WP), until removal by the Sludge Removal System (SRS) after all the fuel has been taken out of the KE Basin.

During recent hot cell characterization efforts, the KE canister sludge released significant amounts of hydrogen gas (Makenas 1996b). This hydrogen gas evolution is believed to result from uranium metal or uranium hydride reaction with water. This observation leads to the question whether the sludge inventory in the WP would generate unacceptable amounts of hydrogen gas and heat from uranium corrosion and SNF radiolytic decay. A Technical Safety Requirement (TSR) limits the basin water temperature to $38^{\circ} \mathrm{C}\left(311{ }^{\circ} \mathrm{K}\right)$, based on stress in concrete walls due to the large temperature differences at the water-air interface. This temperature limit does not apply to the submerged SNF in the basin and may not apply to the siudge stored in the WP.

\subsection{Objective}

The objective of this document is to determine whether the sludge storage conditions in the KE Basin WP, at the end of fuel retrieval activities and before sludge removal activities, will result in acceptable sludge storage temperatures and hydrogen generation rates. The expected sludge types to be stored in the WP, after fuel retrieval activities are complete, include currently observable canister sludge, FRS-generated "new" sludge (new breakage or existing particulates held within the fuel, referred in following discussion as Primary Clean Machine or PCM sludge), floor sludge, and the existing WP sludge.

\subsection{Conclusions and Recommendations}

The results of this analysis do not provide clear direction on the acceptability of storing the planned sludge volumes in the WP. The primary reason is that many of the important sludge properties, such as reactivity and thermal conductivity of all sludge types and the quantity of FRS sludge, are not well known. A lesser reason is that a simplified time-independent, onedimensional heat transfer model is used to avoiding the complexity and cost of a multi-dimensional, time-dependent heat and mass transfer analysis. Within the large uncertainty of the sludge properties, storing the working bound volume of sludge cannot be shown to be safe, while storing the working estimate volumes appears to be. 
It is clear from this analysis that safe storage of the FRS sludge is much more difficult than safe storage of the Weasel Pit and floor sludges. It is also clear that hydrogen generation rates are low. As long as sludge temperature remains below the heat transfer transition temperature (defined below), the estimated hydrogen generation rate from all the estimated sludge volume is less than $0.4 \mathrm{cfm}$. If the storage temperature exceed the transition temperature, the rate could be about 10 times higher.

The uncertainty in many of the sludge properties required that a range of plausible values be estimated for each property, based on different combinations of referenced information and engineering/scientific judgement. Using reasonable but optimistic sludge properties, the analysis indicates that it may be thermally acceptable to store the FRS sludge in the WP, however, using reasonable but conservative sludge properties indicates that it is not thermally acceptable. The unacceptable situation begins as a temporarily unstable condition where the sludge temperature will continue to slowly rise without control. (This temperature where this begins is referred to hereafter as the heat transfer transition temperature and is approximately $58^{\circ} \mathrm{C}$ for the scenarios evaluated). It continues until there is enough water circulating through the sludge to provide sufficient convective heat removal or until water boils within the sludge; even if no additional sludge is transferred to the WP. In either case, the additional water circulation would carry soluble isotopes from the sludge into the water in the WP and probably significantly overload the IWTS capacity to remove them.

As a result, it is recommended that the current plan of storing the FRS sludge with the floor and the existing WP sludge in the WP be changed. Some of the potential solutions to the thermal problem are listed below. Nonthermal issues, such as criticality safety, will impose additional constraints on all of these solutions.

- Install instrumentation (e.g., thermocouple trees) to monitor the sludge temperature within the WP as the sludge accumulates. If the sludge temperature profiles validate the suite of conservative assumptions included in this analysis, suspend fuel removal activities until an alternate FRS sludge management path can be implemented. Project risk could be reduced to the extent the alternate path was pre-designed or pre-constructed.

- Store the FRS sludge separately in a manner which prevents accumulations approaching an unacceptable distance from the cooling basin water.

- Install a heat removal system throughout the WP.

- Reinstate sludge removal from the WP during fuel removal activities. This activity requires the installation of appropriate equipment and a completed SNFP-TWRS or SNFP-Solid Waste agreement on a sludge disposal path.

Additional recommendations:

- Use a similar analysis to evaluate projected WP conditions, if floor sludge is planned to be transferred to the WP after fuel removal activities begin, but before the sludge removal activities begin. 
- Install a small number of thermocouple trees in the sludge within the WP or the Basin, in the near future. Install them at locations where the sludge has been characterized, and preferably, where deeper sludge accumulations exist. This will allow verification or modification of some of the sludge properties estimated in this analysis, such as thermal conductivities.

\subsection{Method of Analysis}

Heat is generated throughout the stored sludge by radiolytic decay of the irradiated uranium fuel and from the exothermic uranium oxidation reactions. For any given sludge volume, the sludge temperature is determined by the rate at which the heat is generated and the rate that the heat is lost to the surrounding environment. As additional sludge is pumped into the WP, the greater volume of sludge increases the internal heat generation and the thicker sludge layer slows the heat transfer. This increases the temperature in the sludge and the rate of the oxidation reactions, but not the rate of radiolytic decay. As the temperature of the sludge rises, the heat transfer increases until the heat loss again equals the heat generation.

The estimates of the sludge temperature are based on reaction kinetics reported in literature, limited sludge characterization data, and observations of four KE canister sludge samples in a 325 Building hot cell (Makenas 1996b, Baker 1996). The gas generated in the reactive samples was determined to consist mostly of hydrogen. Gas generation rates could be estimated since they were trapped by "plugs" of sludge in the graduated cylinder. The heat generated is correlated with the stoichiometry of the reaction and the surface reaction rate for uranium and water.

The sludge temperature is estimated using a one-dimensional, heat conduction model with the radiolytic decay heat and temperature dependant uranium-water reaction occurring throughout the sludge depth. The analysis recognizes that different sludge types will be deposited in the WP from sequential operations, and evaluates the effect of the different sludge properties (e.g., uranium concentration, reactivity, density, etc.) on the temperature profile. The analysis considers the expected WP condition in early 2000, when there is the maximum accumulation of sludge, i.e., with fuel removal being complete, but sludge removal not yet begun. The second-order differential, heat transfer equations were solved using a Runge-Kutta-Feldberg method (Gerald and Wheatly 1985).

\subsection{Sludge Stored in the Weasel Pit}

The analysis considers three distinct layers of sludge in the WP.

- Layer 1 - lies at the bottom of the WP and consists of the existing assettled WP sludge and any planned early transfers of sludge from basin pits. Its estimated bounding volume is $\left(12 \mathrm{~m}^{3}\right)$ and it has a relatively low concentration of uranium (Baker 1997, Makenas 1996a).

- Layer 2 - lies on top of Layer 2 and consists of the floor sludge retrieved from the West Bay to allow fuel retrieval equipment installation. Its estimated bounding volume is $\left(6.5 \mathrm{~m}^{3}\right)$ and it 
has a relatively low concentration of uranium (Baker 1997, Short 1995).

- Layer 3 - lies on top of Layer 2 and consists of a uniform mix of all of the currently estimated canister sludge and the new sludge

generated from the FRS PCM. The estimated bounding volumes of its two components are $7.4 \mathrm{~m}^{3}$ of canister sludge and $3.0 \mathrm{~m}^{3}$ of $P C M$ sludge; the estimated working volumes are $3.0 \mathrm{~m}^{3}$ and $1.3 \mathrm{~m}^{3}$, respectively. All of this FRS sludge has a high concentration of uranium (Pitner 1997, Omberg 1996).

The concurrent retrieval of floor sludge with fuel removal (known as "Just-in-Time sludge removal") was initially included in the analysis, but later removed when preliminary results indicated the uncertainty of storing all of Layer 3 in the WP. Since safe storage of FRS sludge during fuel removal has higher priority than floor sludge retrieval, the scope of the analysis was narrowed to just the essential sludge storage. Inclusion of additional floor sludge, either mixed with or on top of the FRS sludge, acts as an insulating blanket and further restricts the volume of FRS sludge that can be stored.

\subsection{Simplifications to Heat Transfer Model}

The heat transfer analysis includes a number of simplifications that reduce analytical time and cost, but add conservatism to the results. These simplifications all allow the analyses to be done without using sophisticated, but costly and time-intensive computer modeling. The simplifications are:

- A model with heat transfer in one physical dimension. This model reasonably approximates the storage scenario, since the majority of the heat loss is to the overlying WP water. The heat loss through the walls and floor will not appreciably decrease storage temperatures due to the insulating effect of the concrete and underlying soil.

- This is not a transient model. There is no time dependency included in the analysis, either due to lower reactivity that may result from uranium reacting between the time it is transferred to the WP and the end of the FRS activities, or due to the change in available surface area of the reactive uranium during that period.

- There are no significant mass transfer limitations to the uranium reaction, i.e., the uranium reaction is not slowed by the rate that water migrates to the reactive uranium surfaces.

\subsection{Uncertainty in Heat Transfer Input Data}

The analysis of the sludge temperature within the WP is complicated by the fact that many of the important inputs are not well known. The relative amounts of uranium metal, hydride, and oxide in the visible canister sludge cannot be determined for several months, if at all. The thermal conductivity of the sludge mix expected in the WP is not currently planned to be determined during the scheduled characterization. The amount of sludge that will be generated or released by the FRS activities cannot be determined before fuel retrieval activities begin. The relative amount of uranium metal, hydride, and oxide in the additional canister sludge will not be determined at all. Some inputs are too difficult to accurately determine, 
such as particle size, shape, and distribution of the reactive uranium in the sludge.

Within these limitations, values of the needed inputs are taken or extrapolated from existing characterizations. When little or no specific analytical data exists, input values are estimated based on available 1iterature. The sensitivity of the calculational results is explored by using different reasonable input values. Important assumptions used are listed below and are discussed in more detail in the Attachment:

- Thermal conductivity of sludge in the WP -- existing characterization data does not include any information on the thermal conductivities. A conservative estimate of the WP sludge thermal conductivity was used in most of the calculations, derived from a combination of 25 volume percent sand, 25 volume percent concrete, and 50 volume percent water, and coincidently, is numerically equal to that of water. Thermal conductivity is assumed constant throughout the relatively narrow temperature range in the stored sludge. The sensitivity of the results to this value were evaluated by using an optimistic, alternate value that might result from higher uranium concentrations in the sludge. The alternate value is based on a combination of 25 volume percent $\mathrm{UO}_{2}, 25$ volume percent $U$ metal, and 50 volume percent water, and is double that of the base value.

- Uranium reactivity of sludge in the WP -- the reactivity of the uranium in the different sludge types depends on the uranium surface area available for reaction and the particular uranium compound that is reacting. Uranium metal and uranium hydride can be quite reactive, while uranium di-oxide and uranium tri-oxide are not (WHC 1996). There is no specific characterization data on reactive surface area in the sludge or on the concentrations of the different uranium compounds. There is information on the total uranium concentration from the completed analysis on the floor sludge and WP sludge, and from the preliminary analysis on the canister sludge (Makenas 1996a, Omberg 1996). There is also hot cell data on the hydrogen gas generation from four canister sludge samples (Makenas 1996b). The effective reactive surface area per unit mass of the uranium and thus uranium reactivity of canister sludge has been estimated from the hot cell data and uranium reaction kinetics. The reactivity of the uranium in the other types of sludge has been estimated relative to the most reactive sample of canister sludge in the hot cell, based on qualitative information, i.e., the hot cell canister sludge is more reactive than the floor sludge and WP, and less reactive than the PCM sludge.

Based on the following rationale, the metal to oxide reaction has been used as the conservative basis for the uranium reaction occurring in the sludge.

1) There are a several uranium oxidation reactions that could be occurring in the sludge, including metal to oxide, metal to hydride, and hydride to oxide. Characterization activities indicate that the gas evolved from the hot cell samples was predominately hydrogen, suggesting that the metal to hydride reaction, with its oxygen gas product, does not occur to any significant extent (Makenas 1996b). However to date, 
characterization activities have not been able to identify whether the reactive uranium is mostly metal or hydride.

2) Comparing the uranium metal reaction to the uranium hydride reaction (WHC 1996, Weast 1988, Wilkerson 1962) i.e.:

$$
\begin{aligned}
& \frac{1}{2} \mathrm{U}+\mathrm{H}_{2} \mathrm{O}=\frac{1}{2} \mathrm{UO}_{2}+\mathrm{H}_{2}+62 \mathrm{Kcal} \text { per gm-mole } \mathrm{V} \\
& \frac{2}{2} \mathrm{UH}_{3}+4 / 7 \mathrm{H}_{2} \mathrm{O}=2 / 7 \mathrm{UO}_{2}+\mathrm{H}_{2}+45 \mathrm{Kcal} \text { per } 2 / 7 \text { gm-mole } \mathrm{U}
\end{aligned}
$$

shows that nearly twice as much metal must react to produce the same hydrogen gas as the hydride and will release about $40 \%$ more heat.

3) Uranium metal reacts in water to form mostly oxide, with 2-9\% hydride depending on reaction conditions, but the aqueous reaction rate of uranium hydride within the mix is not known (WHC 1996). For pure uranium hydride, the reaction rate changes (slows exponentially) over time, from what is believed to be mass transfer effects. Use of the hydride reaction kinetics would force a time-dependent analysis and add additional uncertainty through the assumption of the initial reaction rate.

4) The PCM sludge will certainly contain uranium metal in the exposed surfaces of the newly created pieces.

5) A knowledge that the results of the analysis are more strongly influenced by decay heat than reaction heat (as will be shown in the discussion of results).

The relative reactivity of the uranium in the sludge types is included through an adjustment to the effective reactive surface area per mass, which is referred to as a rate multiplier (RM). The uranium in the most reactive canister sludge sample is assigned an $\mathrm{RM}$ of 1.0. A rate multiplier less than 1.0 is estimated for the uranium in all of the canister sludge in the basin, based on the volume of $\mathrm{H}_{2}$ gas given off in the remaining hot cell samples and the assumption that these four samples are representative of the canister sludge inventory. An RM of 1.0 is assigned to the uranium in the PCM sludge, based on opposing factors that it will contain fuel pieces created by mechanical action that have a large fraction of unreacted fuel surfaces (implying relative high reactivity), but will likely contain larger size particles (lower surface area per mass) than canister sludge that has been subject to the molecular level corrosion process.

The sensitivity of the WP sludge temperature to this relative reactivity was evaluated using alternate values. In one case, it is assumed that on average, the uranium in the FRS sludge is twice as reactive as the average of the hot cell samples. In the other case, it is assumed that uranium in the FRS sludge is not reactive at all.

- Densities of the WP sludge layers range from 1.5 to $3.0 \mathrm{~g} / \mathrm{cm}^{3}$ - taken from characterization data for KE Basin sludge (Makenas 1996a, Baker 1996, Short 1995). 


\section{HNF-SD-SNF-TI-047, Rev 0}

- Decay heat from the uranium in the KE Basin sludge types is taken as the average value of the fuel in the KE Basin. This value is conservative since it includes soluble isotopes such as cesium and strontium, that can be released from the fuel matrix when the uranium metal reacts. If released and able to mix with the KE Basin water, soluble isotopes will be removed by the ion exchange resin. The sensitivity of the WP sludge temperature to decay heat was evaluated in an alternate case, using only $60 \%$ of the decay heat per mass in the intact uranium fue 1 , based on the reduced concentration of cesium and strontium in the characterized floor and WP sludge (Makenas 1996a).

\subsection{Summary of Results}

The results are presented in Figures 1 through 5 , showing the temperature profile of the sludge from the water-sludge interface to the bottom of the WP. In none of the cases considered, except the higher thermal conductivity case, could the working bound sludge volume be shown to be stored thermally safe in the WP. The working estimate sludge volume would be able to be stored thermally safe, but would require active sludge management to evenly distribute the sludge throughout the WP. Also, this estimated sludge volume provides little additional safety margin over that inherent in the conservative assumptions used in the calculations. Allowed sludge volumes are limited by the $58{ }^{\circ} \mathrm{C}$ heat transfer transition temperature above which localized water boiling within the sludge could result, rather than the $38{ }^{\circ} \mathrm{C}$ TSR on basin water temperature.

The most likely storage situation, uses the following input values:

$$
\begin{array}{ll}
\text { Layer } 1- & \text { sludge density }=1.5 \mathrm{~g} / \mathrm{cm} 3), \\
\text { thermal conductivity }=6.0 \times 10^{-6} \mathrm{~kW} / \mathrm{K}-\mathrm{cm}, \\
\text { uranium concentration }=0.033 \mathrm{~kg} \mathrm{U} / \mathrm{kg} \mathrm{WP} \text { sludge, and } \\
\mathrm{RM}=0.25
\end{array} \text { Layer } 2-\quad \begin{aligned}
& \text { sludge density }=1.5 \mathrm{~g} / \mathrm{cm}^{3}, \\
& \text { thermal conductivity }=6.0 \times 10^{-6} \mathrm{~kW} / \mathrm{K}-\mathrm{cm}, \\
& \text { uranium concentration }=0.030 \mathrm{~kg} \mathrm{U} / \mathrm{kg} \mathrm{WP} \text { sludge, and } \\
& \text { RM }=0.25
\end{aligned}
$$

In the sensitivity cases, these values were varied separately while the remaining baseline values were held constant. The results of the analyses are discussed below. In all cases described, the temperature of the water above the sludge is maintained at $10^{\circ} \mathrm{C}$ by the water chillers. Loss of cooling reduces the allowed sludge inventory in all cases considered by approximately $7-9 \mathrm{~cm}\left(1-1.5 \mathrm{~m}^{3}\right)$, if the water temperature rises to $20^{\circ} \mathrm{C}$.

\section{Figure 1: Baseline Values}

Using the baseline variables, the sludge bottom temperature would maintain a stable temperature of $331^{\circ} \mathrm{K}\left(58^{\circ} \mathrm{C}\right)$ at a sludge depth of about $160 \mathrm{~cm}\left(26 \mathrm{~m}^{3}\right)$ 


$$
\text { HNF-SD-SNF-TI-047, Rev } 0
$$

with the sludge/water interface temperature at $283^{\circ} \mathrm{K}\left(10^{\circ} \mathrm{C}\right)$. However, using the conservative volumes given for sludge (Pitner 1997, Baker 1997) a tota] sludge depth of $180 \mathrm{~cm}\left(29 \mathrm{~m}^{3}\right)$ would require storage in the WP. Using the working estimate volumes provided, a total sludge depth of $140 \mathrm{~cm}\left(23 \mathrm{~m}^{3}\right)$ is required.

The estimated hydrogen generation rate at these baseline conditions is $0.34 \mathrm{cfm}$ if all the potential sludge were stored at the $58{ }^{\circ} \mathrm{C}$ temperature.

The figure clearly shows that the properties of the FRS sludge are by far the most significant to the estimated WP profile.

\section{Figure 2: Storage Temperature Stability}

Using the baseline values, a family of curves is displayed that shows the gradual rise in the temperature profile of the sludge as additional sludge is added to the WP. Notice at a depth of about $160 \mathrm{~cm}\left(26 \mathrm{~m}^{3}\right)$ the sludge bottom temperature begins to become unstable - large temperature increases result from small depth increases and then becomes unstable (evidenced as a solution of two bottom temperatures $\left(331^{\circ} \mathrm{K}\right.$ and $\left.336^{\circ} \mathrm{K}\right)$ at one sludge depth.

\section{Figure 3: Uranium Reactivity}

By varying RM values for the most sensitive layer, Layer 3, these three curves show the relative importance of the uranium reaction term. The RM value of zero corresponds to the bounding case of no reactivity, while the RM value of 1.64 corresponds to twice the reactivity of the base case. The lower reactivity case allows the storage of approximate $7 y 175 \mathrm{~cm}\left(28 \mathrm{~m}^{3}\right)$ additional sludge, while the higher reactivity case would reduce the allowed storage to $154 \mathrm{~cm}\left(25 \mathrm{~m}^{3}\right)$.

\section{Figure 4: Thermal Conductivity}

This figure shows the effect of two different thermal conductivity values (k), one value representing the base case (a water, sand, and concrete mix $[k=6.0$ $\left.x 10^{-6} \mathrm{~kW} / \mathrm{K}-\mathrm{cm}\right]$ that is coincidentally the same as water itself) and the other value plausibly representing a uranium and water mix, with twice as much thermal conductivity. The higher thermal conductivity case marginally allows the storage of all of the estimated sludge $180 \mathrm{~cm}\left(29 \mathrm{~m}^{3}\right)$.

\section{Figure 5: Decay Heat}

This figure shows the effect of two different decay heats for the sludge, one representing base case of $0.073 \mathrm{~W} / \mathrm{Kg}$ of uranium (the average of the irradiated fuel inventory) and the other representing the lower bound of the floor and WP sludge at $0.044 \mathrm{~W} / \mathrm{Kg}$ of uranium. The lower decay heat case allows the storage of approximately $168 \mathrm{~cm}\left(27 \mathrm{~m}^{3}\right)$ of sludge. 
HNF-SD-SNF-TI-047, Rev. 0

Figure 1: Baseline Values

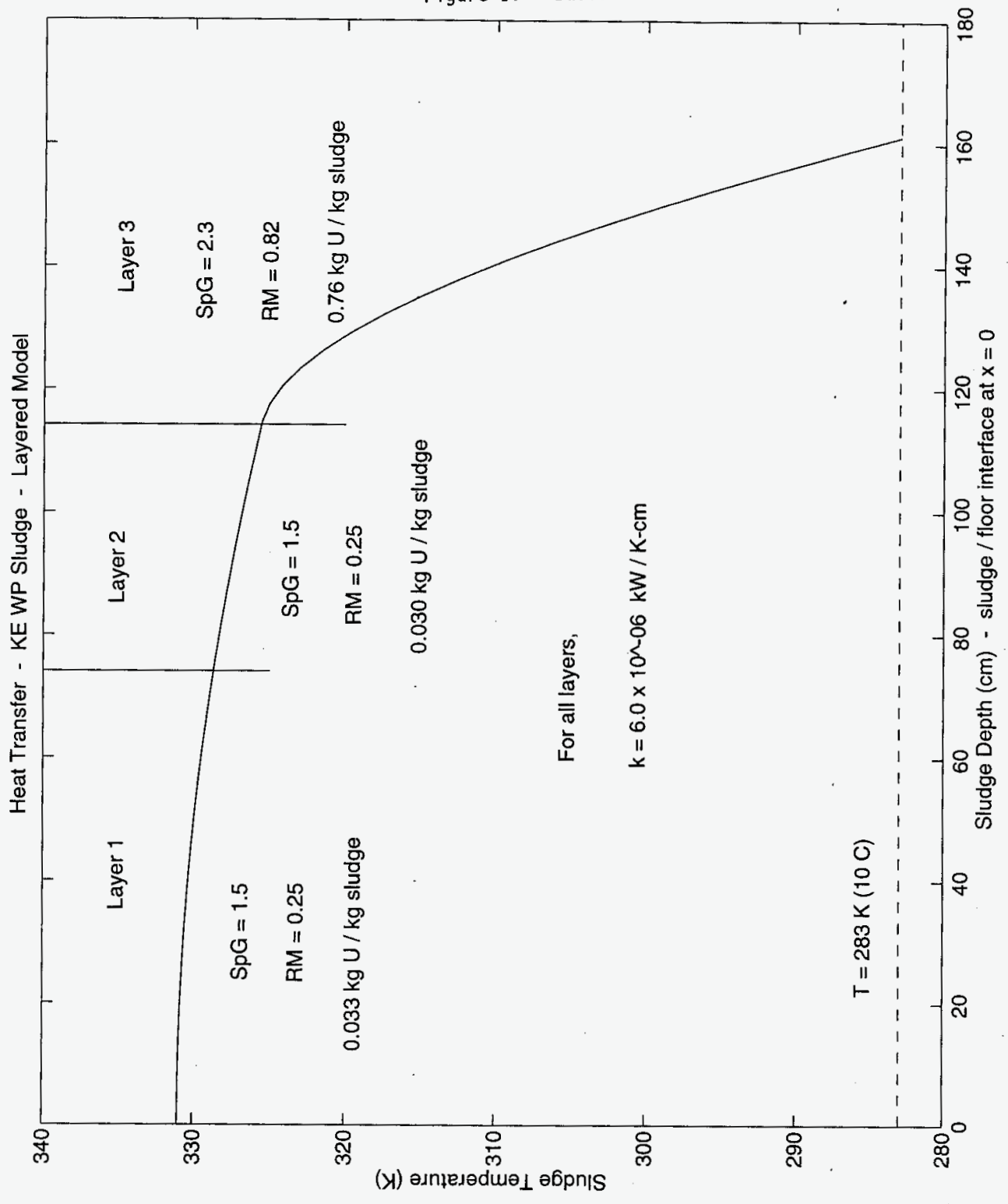


HNF-SD-SNF-TI-047, Rev. 0

Figure 2: Storage Temperature Stability

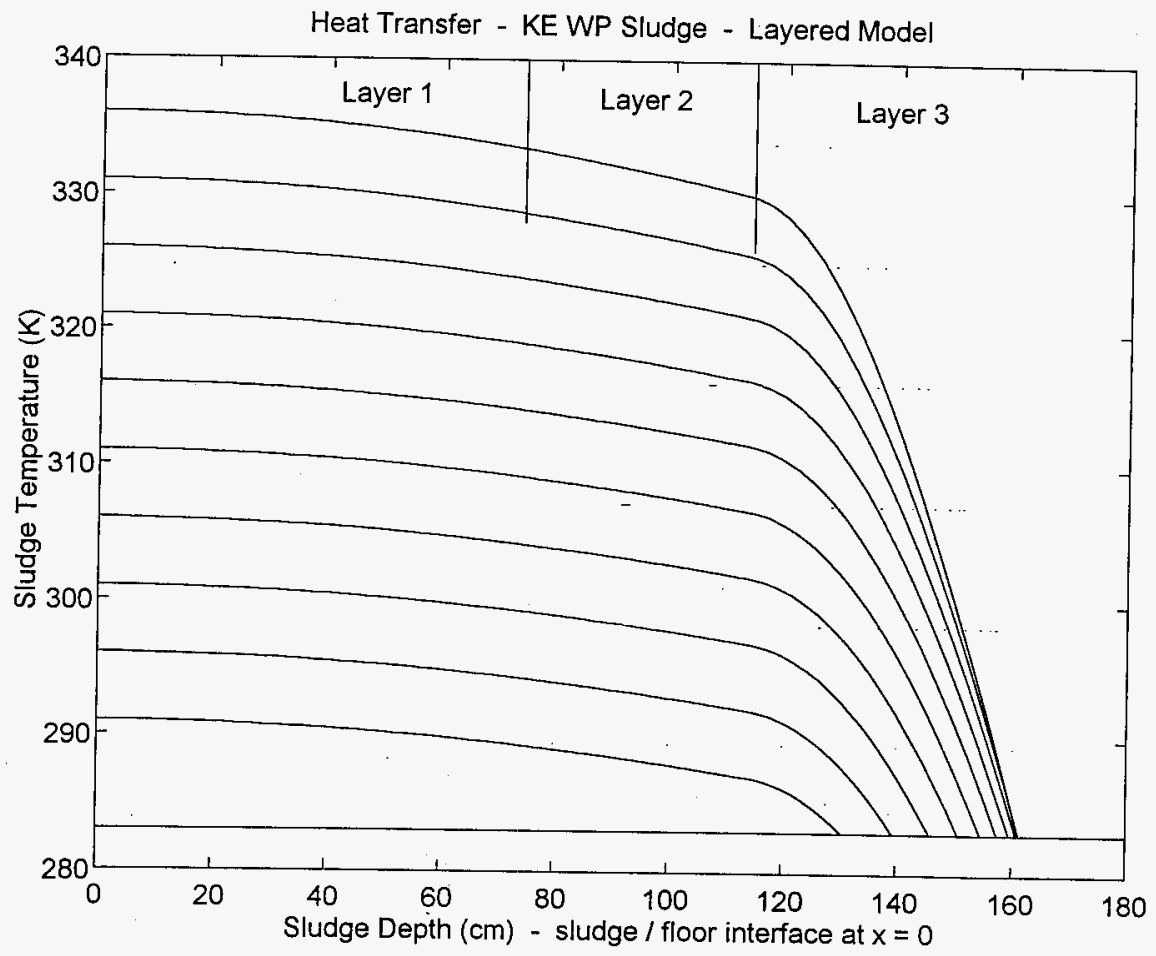


HNF-SD-SNF-TI-047, Rev. 0

Figure 3: Uranium Reactivity

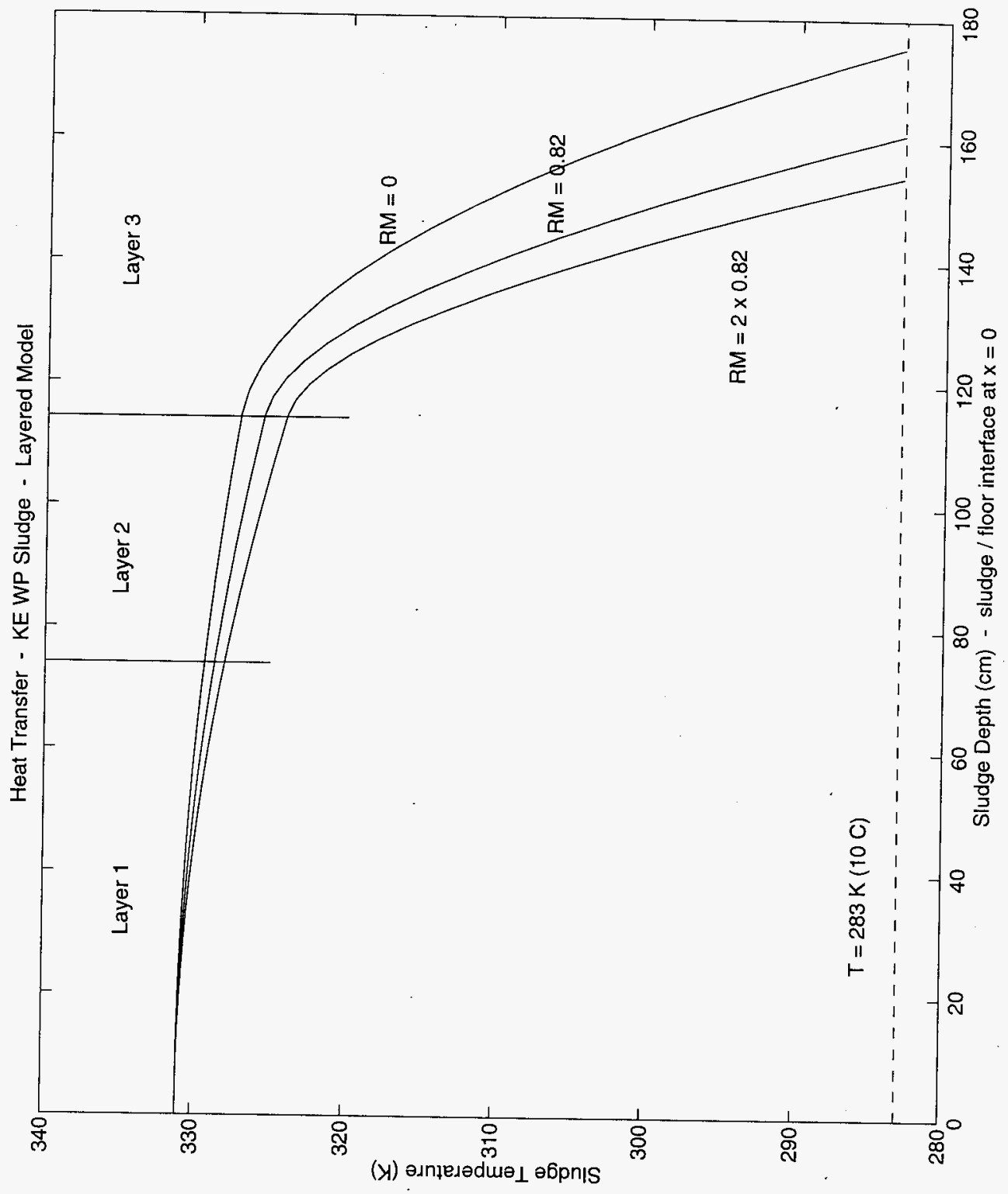


HNF-SD-SNF-TI-047, Rev. 0

Figure 4: Thermal Conductivity

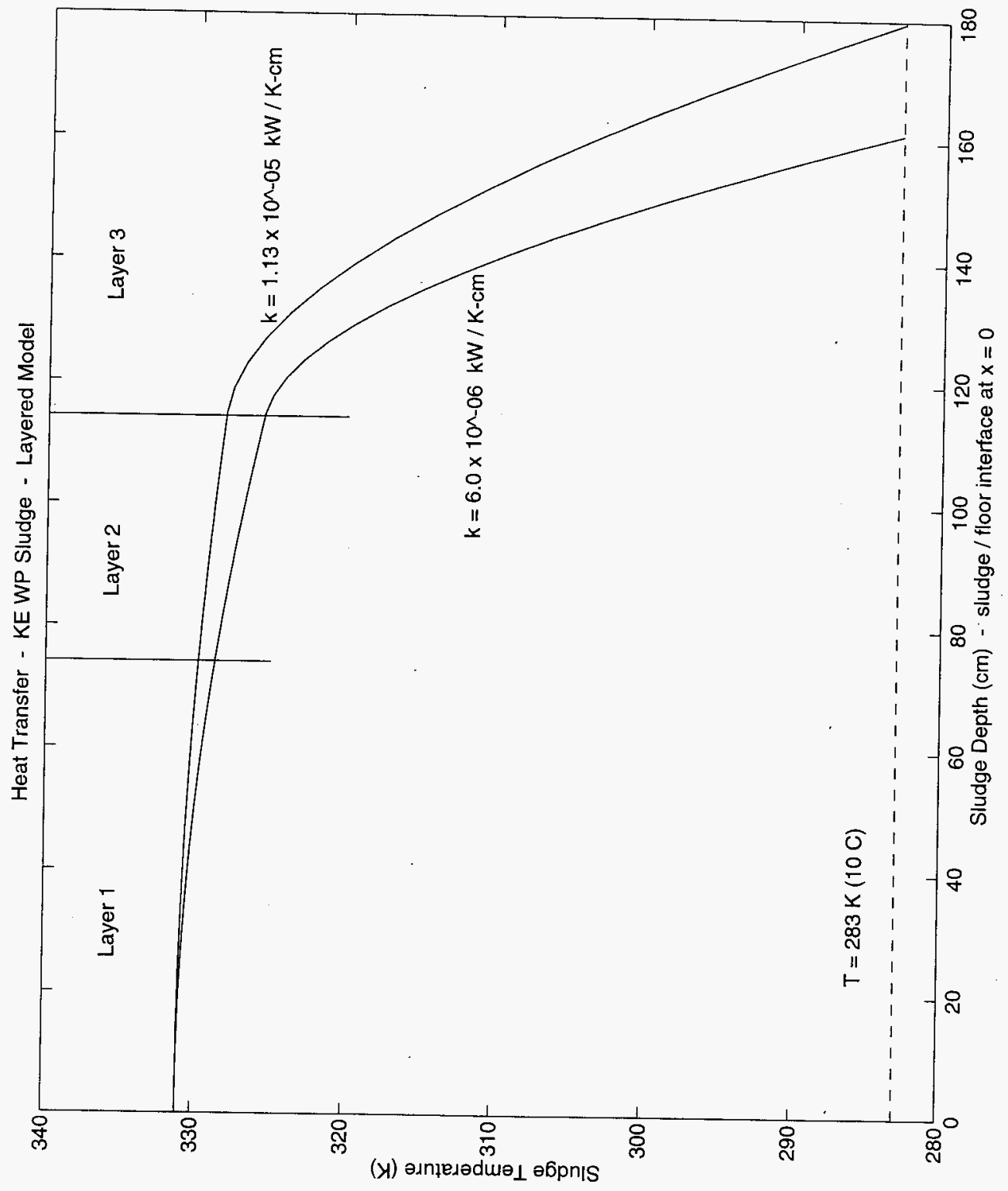




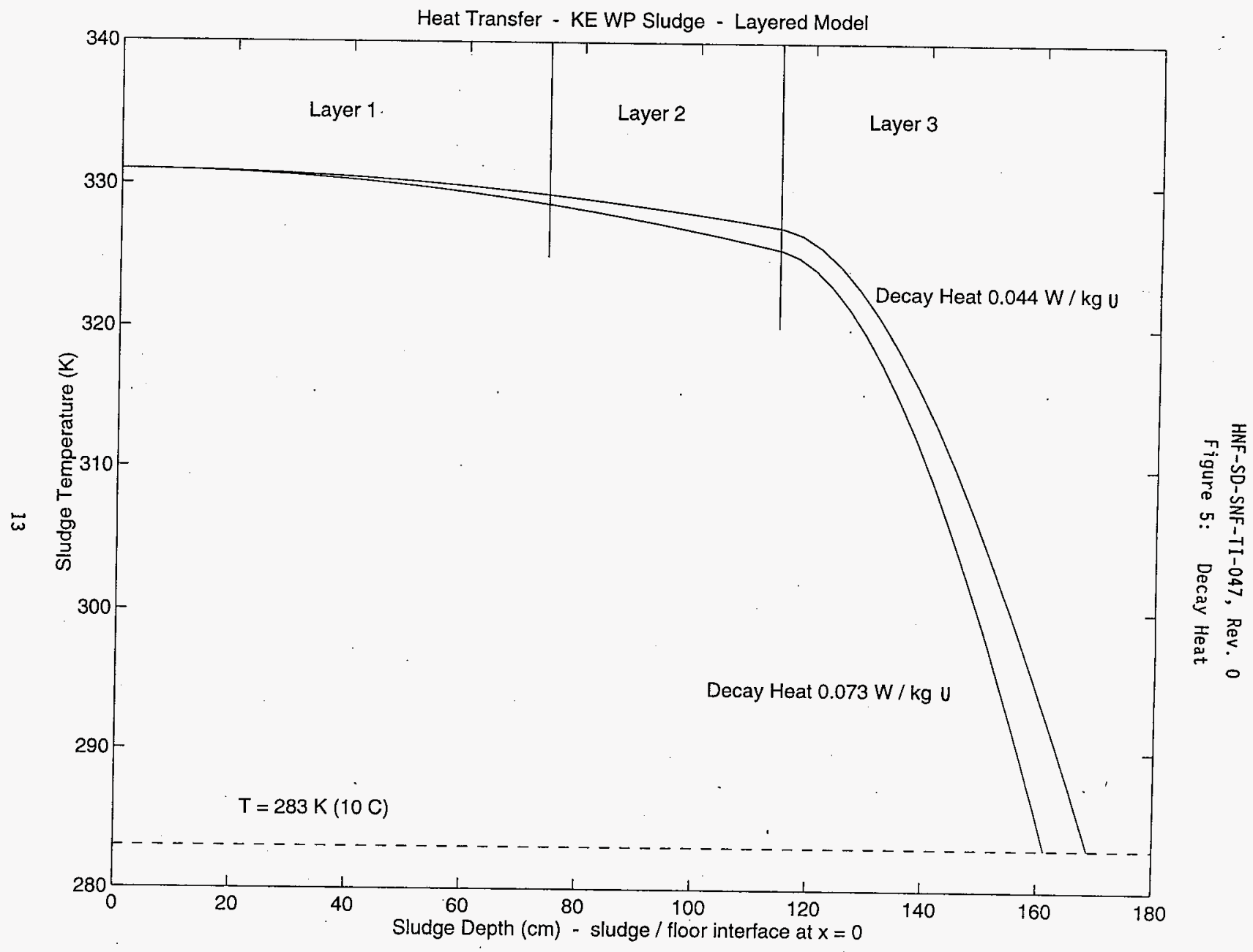




\subsection{References}

Baker, R. B. 1997, Draft letter to K. L. Pearce, DESH, dated January 27, 1997 , Revised Estimates of Sludge Volume in $K$ East and $K$ West Basins, Duke Engineering and Services Hanford, Incorporated, Richland, Washington.

Baker, R. B. 1996 Letter Correspondence Number 9654989, dated November 1, 1996, Letter of Instruction (LOI) Part III for Detailed Laboratory Analyses of Sludge Samples Taken from the K East Fuel Storage Canisters, Duke Engineering and Services Hanford, Incorporated, Richland, Washington.

LaMarsh, J. R., 1977, Introduction to Nuclear Engineering, Addison-Wesley Publishing Company, Reading, Massachusetts

Makenas B. J., 1996a, Analys is of Sludge from Hanford K East Bas in Floor and Wease1 Pit, WHC-SP-1182, Westinghouse Hanford Company, Richland, Washington.

Makenas, B. J., 1996b, Letter Correspondence Number 9654398, dated September 26, 1996, Highlight Report On Observations in K East Basin Canister Sludge During Analysis, Westinghouse Hanford Company, Richland, Washington.

Omberg R. P., 1996 Letter Correspondence Number DESH-9655840, dated November 21, 1996, Highlight Report: Accelerated Examinations of K East Basin Canister Sludge, Duke Engineering and Services Hanford, Incorporated, Richl and, Washington.

Pitner, A. L, 1997, Letter to D. S. Takasumi, DESH, dated January 23, 1997, K East Basin Sludge Volume Estimates for Integrated Water Treatment System, Duke Engineering and Services Hanford, Incorporated, Richland, Washington.

Short, S. M., and M. M. Beary, 1995, Spent Nuclear Fuel Project Technical Databook, WHC-SD-SNF-TI-015, Rev 0, Westinghouse Hanford Company, Richland, Washington.

Weast, R. C., 1988, Handbook of Chemistry and Physics, 69th edition, CRC Press, Boca Raton, Florida.

WHC, 1996, Spent Nuclear Fuel Project (SNFP) Gas Generation From N-Fuel in Multi-Canister Overpacks, WHC-SD-SNF-TI-028, Rev 0 , Westinghouse Hanford Company, Richland, Washington.

Wilkinson, W. D., 1962, Uranium Metallurgy, Volume II: Uranium Corrosion and Alloys, Interscience Publishers, New York, New York.

Willis, W. L., and A. N. Praga, 1995, 105-K Basin Material Design Basis Feed Description For Spent Nuclear Fuel Project Facilities, WHC-SD-SNF-TI009, Rev 0, Westinghouse Hanford Company, Rich1and, Washington. 
HNF-SD-SNF-TI-047, Rev. 0

\section{Attachment: Heat and Hygrogen Gas Generation and Transfer in KE Weasel Pit Sludge}

\section{Heat Generation Sourceg in Sludge}

Heat is generated in the Weasel Pit (WP) by two different mechanisms. One mechanism is the chemical or corrosion reaction of available (uncorroded or unoxidized) uranium within the sludge and the other is the radiolytic decay of the isotopes within the irradiated uranium fuel matrix.

\section{A. Corrosion Reaction Heat}

Sludge is stored in the WP in a flooded condition. The predominant uranium-water reactions are as follows:

$$
\begin{gathered}
\mathrm{U}+2 \mathrm{H}_{2} \mathrm{O} \rightarrow \mathrm{UO}_{2}+2 \mathrm{H}_{2}+\text { heat }(1) \quad 91 \% \\
4 \mathrm{U}+6 \mathrm{H}_{2} \mathrm{O}-\rightarrow 4 \mathrm{UH}_{3}+3 \mathrm{O}_{2}+\text { heat }(2 \mathrm{a}) 9 \% \\
2 \mathrm{UH}_{3}+4 \mathrm{H}_{2} \mathrm{O} \rightarrow 2 \mathrm{UO}_{2}+7 \mathrm{H}_{2}+\text { heat }(2 \mathrm{~b})
\end{gathered}
$$

As mentioned in the main text of this document, the above uranium metal/water reaction rate (1) is conservatively assumed to be the hydrogen gas generating reaction taking place in the stored WP sludge. The stoichiometric and reaction heat values for this reaction will be utilized

as appropiate in further calculations.

\section{Reaction Rate Equations}

In order to determine the rate of heat release, the rate at which uranium reacts with water must be determined.

Reaction rate equations for uranium-water reactions are given in WHC-SD-SNF-TI-028, Rev.0 (Cooper 1996).

Oxygen: $\quad \mathrm{K}^{\mathrm{O}}=10^{(7.364-3016 / \mathrm{T})}$ for $\mathrm{T}<373^{\circ} \mathrm{K}$

where $\mathrm{K}^{\mathrm{O} 2}[=] \mathrm{mg} \mathrm{O} / \mathrm{cm}^{2} \mathrm{U}-\mathrm{hr}$

On a mole basis - gmole $0_{2} / \mathrm{cm}^{2} \mathrm{U}-\mathrm{hr}$

$\mathrm{K}^{02}=3.125 \times 10^{-5} \times 10^{(7.364-3016 / \mathrm{T})}[=]$ gmole $0_{2} / \mathrm{cm}^{2} \mathrm{U}-\mathrm{hr}$

Uranium: Since there is 1 mole of $\mathrm{O}_{2}$ consumed foreach mole of uranium - gmole $\mathrm{U} / \mathrm{cm}^{2} \mathrm{U}-\mathrm{hr}$,

$$
\mathrm{K}^{\mathrm{Um}}=3.125 \times 10^{-5} \times 10^{(7.364-3016 / \mathrm{T})}[=] \text { gmole } \mathrm{U} / \mathrm{cm}^{2} \mathrm{U}-\mathrm{hr}
$$


HNF-SD-SNF-TI-047, Rev. 0

On a mass basis ( $\mathrm{kg} \mathrm{U} / \mathrm{Cm}^{2} \mathrm{U}-\mathrm{hr}$ )

$$
\mathrm{K}^{\mathrm{Ukg}}=7.43 \times 10^{-6} \times 10^{(7.364-3016 / \mathrm{T})}[=] \mathrm{kg} \mathrm{U} / \mathrm{cm}^{2} \mathrm{U}-\mathrm{hr}
$$

The rate of uranium reaction within the sludge depends on the sludge temperature and the available surface area of the reactive uranium.

Hydrogen: Since there are 2 moles of $\mathrm{H}_{2}$ generated for each mole of uranium consumed,

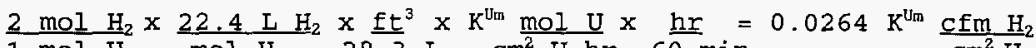
$1 \mathrm{~mol} \mathrm{U}$ mol $\mathrm{H}_{2} \quad 28.3 \mathrm{~L}$ $\mathrm{cm}^{2} \mathrm{U}-\mathrm{hr} \quad \frac{\mathrm{hr}}{60 \mathrm{~min}}$ $\frac{\mathrm{cm} \mathrm{Cm}^{2} \mathrm{U}}{\mathrm{Cm}^{2}}$ 


\section{HNF-SD-SNF-TI-047, Rev, 0}

\section{1) Available Uranium Surface Area for Reaction}

The reactive uranium in the sludge depends on the uranium mass concentration in the sludge and the available sludge. The available surface area of the sludge is determined by the particle shape and the particle size distribution of the reactive uranium in the sludge. There are two "sources" of uranium. One is the existing inventory dispersed throughout the basin and the canisters. The other is that generated/released by the fuel cleaning process from the Fuel Retrieval System (FRS).

\section{Estimate of Uranium in KE Basin Sludge Types}

The volume of existing as-settled sludge in the WP is estimated at an upper bound of $12 \mathrm{~m}^{3}$ (Baker 1997) with an average uranium concentration of $3.3 \mathrm{w} / \mathrm{w} \% \mathrm{U}$ (Makenas 1996a) and a bulk density of $1.5 \mathrm{~g} / \mathrm{cm}^{3}$ (Short 1995). The upper bound volume of the as-settled floor sludge in the west bay, expected to be retrieved for equipment installation, has been estimated at $6.5 \mathrm{~m}^{3}$ (Baker 1997) with an estimated $3.0 \mathrm{w} / \mathrm{w} \% \mathrm{U}$ (Makenas 1996a) as an average value. The quantity of canister sludge has a "working bound" estimate of $7.4 \mathrm{~m}^{3}$ (Pitner 1997) with an average bulk specific gravity of 2.0 $\mathrm{gm} / \mathrm{cm}^{3}$ (Baker 1996). The quanitity of FRS-generated fuel "chips" has a working bound estimate of $3.2 \mathrm{~m}^{3}$ (Pitner 1997). Since characterization of the current canister sludge inventory is only beginning, there is little quantitative information available. Initial characterization indicates an as-settled uranium content is 60-85 w/wo (Omberg 1996); however, the amount or fraction of available reactive uranium is unknown at present. This sludge also includes significant quantities of non-uranium material.

Uranium concentrations are shown below for the storage of expected sludge layers in the WP. It is assumed in this analysis that no floor sludge will be transferred to the wP, other than the $6.5 \mathrm{~m}^{3}$ from the west bay, until after all fuel has been removed from the KE Basin (i.e., no "just-in-time" sludge retrieval) and sludge removal capability has been installed. The uranium concentration of the top layer

(Layer 3) is calculated from the estimated amount of each sludge type coming from the FRS activities and weighted with the associated uranium concentration for each (Makenas 1996a) to result in an average uranium composite for the Layer 3 sludge. 
FNF-SD-SNF-TI-047, Rev. 0

As-settled sludge $\left(\mathrm{m}^{3}\right)\left(\mathrm{kg} / \mathrm{m}^{3}\right)$ Conc. $(\mathrm{kg} \mathrm{U} / \mathrm{kg}$ sldg) Amt. (kg U)

Layer 1

Existing

WR sludge

(12) $\left(1.5 \times 10^{3}\right)$

0.033

$0.59 \times 10^{3}$

Layer 2

Floor sludge

from Equip.

Installation

$(6.5)\left(1.5 \times 10^{3}\right)$

0.03

$0.29 \times 10^{3}$

Layer 3

Can. Sludge*

$(7.4)\left(2.0 \times 10^{3}\right)$

0.60

$8.9 \times 10^{3}$

FRS Generated

"Chips"

$(3.2)\left(3.0 \times 10^{3}\right)$

1. 0

$9.6 \times 10^{3}$

Total sludge

stored in

Layer 3

$24.4 \times 10^{3} \mathrm{~kg}$ sludge

(10.6 $\mathrm{m}^{3}$ as-settled sludge)

$18.5 \times 10^{3}$

Total sludge

Stored in WP

$$
\begin{aligned}
& 52.2 \times 10^{3} \mathrm{~kg} \text { sludge } \\
& \left(29.1 \mathrm{~m}^{3}\right. \text { as-settled sludge) }
\end{aligned}
$$

$19.4 \times 10^{3} \mathrm{~kg} \mathrm{U}$

* Note: The density $2.0 \times 10^{3} \mathrm{~kg}$ bulk can.sludge $/ \mathrm{m}^{3}$ can. sludge $(2.0 \mathrm{~g} / \mathrm{ml})$ is the average value calculated from the four canister sludge samples taken (Baker 1996). The uranium concentration in the canister sludge is taken as $0.60 \mathrm{~kg} \mathrm{U} / \mathrm{kg}$ since this could roughly correlate to a density of $2.0 \mathrm{~g} / \mathrm{ml}$ and it lies within the sample range of 60-85 w/wo U (Omberg 1996).

Therefore,

Avg. Layer 3

$\mathrm{U}$ conc. $=\frac{18.5 \times 10^{3} \mathrm{~kg} \mathrm{U}}{24.4 \times 10^{3} \mathrm{~kg} W P \text { sludge }} \approx 0.76 \mathrm{~kg} \mathrm{U} / \mathrm{kg}$ WP sludge

Avg. Layer 3

Density $=\frac{7.4\left(2.0 \times 10^{3}\right)+3.2\left(3.0 \times 10^{3}\right)}{10.6}=2.3 \times 10^{3} \mathrm{~kg} / \mathrm{m}^{3}$

$$
\text { A-4 of } 16
$$


Available Surface Area per Mass (A/M)

Only the particle size distribution of the WP and floor sludge samples have been characterized. Uranium metal and particle shape distributions are not known. Even less information is available on the canister sludge. Despite this, the effective surface area can be estimated from the 325 Lab observation of $\mathrm{H}_{2}$ generating canister sludge. For use in this document, the effective surface area per mass of $K E$ canister sludge will be the reference basis for the entire quantity of sludge expected to be stored in the WP. A weighting factor will be later introduced and associated with the different quantities or fractions of sludge expected to be stored in the WP. The most reactive sample of $\mathrm{KE}$ canister sludge will be the reference basis for the magnitude of the individual weighting factors.

An observation of the most reactive sample (Makenas 1996b) shows approximately $650 \mathrm{ml}$ gas was generated by $280 \mathrm{ml}$ of sludge* over 5 days at $36^{\circ} \mathrm{C}$.

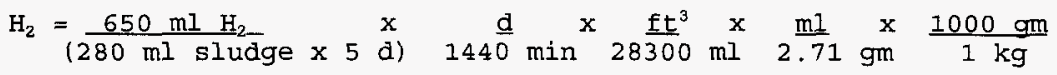

$=4.2 \times 10^{-6} \mathrm{cfm} \mathrm{H}_{2}$ generated $/ \mathrm{kg} \mathrm{KE}$ canister sludge

* Note: $280 \mathrm{ml} \times 2.71 \mathrm{gm} / \mathrm{ml}=760 \mathrm{gm} \mathrm{KE}$ canister sludge in the sample. The sludge density of $2.71 \mathrm{gm} / \mathrm{ml}$ is the value given for that sample (Makenas 1996b).

From kinetics:

$$
\begin{aligned}
\mathrm{H}_{2} \text { gen } & =0.0264 \mathrm{~K}^{\mathrm{Um}} \times \frac{\mathrm{A}}{\mathrm{M}} \times \mathrm{U}_{\text {Conc }} \\
& {[=] \frac{\mathrm{cfm} \mathrm{H}_{2}}{\mathrm{~cm}^{2} \mathrm{U}} \times \frac{\mathrm{cm}^{2}}{\mathrm{~kg}} \frac{\mathrm{U}}{\mathrm{U}} \times \frac{\mathrm{kg} \mathrm{U}}{\mathrm{kg} \mathrm{KE}} \text { canister sludge } } \\
& {[=] \underset{\mathrm{kg} \mathrm{KE}}{\frac{\mathrm{cfm}}{\mathrm{K}} \mathrm{H}_{2}} \text { can. sludge } }
\end{aligned}
$$

Therefore, solving for $\frac{A}{M}$ :

$$
\begin{aligned}
\frac{\mathrm{A}}{\mathrm{M}} & \left.=\frac{\underline{\mathrm{H}}_{2} \frac{\mathrm{gen}}{\mathrm{0}}}{\left(0.0264 \mathrm{~K}^{\mathrm{Um}}\right.}\right) \times \mathrm{U}_{\mathrm{Conc}} \\
& =\frac{4.2 \times 10^{-6}}{(0.0264)\left(3.125 \times 10^{-5}\right) \times 10^{(7.364-3016 / \mathrm{T})} \times 0.85}
\end{aligned}
$$


HNF-SD-SNF-TI-047, Rev. 0

\section{$=\quad 1500 \mathrm{~cm}^{2} \mathrm{U} / \mathrm{kg} \mathrm{U}$}

\section{Weighting Factor}

A weighting factor or rate multiplier (RM) is introduced to reflect the different composite reactivities of the uranium mix in the different sludge types. The overall reactivity of each sludge type is a combination of the reference reactive surface area uranium per mass uranium $(A / M)$, the uranium concentration, and the $R M$ value relative to the reference $A / M$ value. An average $\mathrm{RM}$ is calculated for the two Layer 3 sludge types. The most reactive sample of the four $\mathrm{KE}$ canister sludge samples is used as the reference basis and assigned a value of $\mathrm{RM}=1$, as shown below:

$R M=\frac{(A / M\rangle^{2}}{(A / M)_{\text {ref }}}$ ludge type $\quad$ where $\langle A / M)_{r o f}=1500 \frac{\mathrm{cm}^{2}}{\mathrm{~kg}} \mathrm{U}$

The RM values associated with the available uranium in each sludge type either increase or decrease the effective surface area per mass, depending on their assumed reactivity, or "weighting", relative to the reactivity of the lab reference sample. The RM value for the less reactive canister sludge samples is assumed to be 0.25 , since these samples generated $\mathrm{H}_{2}$ gas ranging from 8 - $38 \%$, which is the average volumetric rate fraction (approximately 25\%) of the most reactive sample.

Therefore, assuming an equal mass of sludge in each sample, the RM value for the canister sludge, on an as-settled basis, is calculated as :
$0.25 \frac{\mathrm{m}^{3}}{\mathrm{~m}^{3} \text { mixed }} \times\left(2.7 \times 10^{3} \frac{\mathrm{kg}}{\mathrm{m}^{3}}\right) \times 0.85 \frac{\mathrm{kg} \mathrm{U}}{\mathrm{kg}} \times 1500 \frac{\mathrm{cm}^{2}}{\mathrm{~kg} U} \times 1.0+$
$0.75 \frac{\mathrm{m}^{3}}{\mathrm{~m}^{3} \text { mixed }} \times\left(1.7 \times 10^{3} \frac{\mathrm{kg}}{\mathrm{m}^{3}} \times 0.60 \underset{\frac{\mathrm{kg} \mathrm{U}}{\mathrm{kg}}}{0} \times 1500 \underset{\mathrm{kg}}{\frac{\mathrm{cm}^{2}}{\mathrm{Ug}} \times 0.25}\right.$
$=1.0 \frac{\mathrm{m}^{3}}{\mathrm{~m}^{3}} \mathrm{mixed}\left(2.0 \times 10^{3} \underset{\mathrm{m}^{3}}{\frac{\mathrm{kg}}{3}} \times 0.61 \frac{\mathrm{kg} \mathrm{U}}{\mathrm{kg}} \times 1500 \underset{\mathrm{kg}}{\frac{\mathrm{cm}^{2}}{\mathrm{~kg}}} \mathrm{U} \times \mathrm{RM}_{\text {Can Sludge }}\right.$

Solving for $\mathrm{RM}_{\text {Can }}$ sludge

$\mathrm{RM}_{\text {Can Sludge }}=0.63$ 
The RM value associated with the available uranium in the existing WP sludge and floor sludge from equipment installation is conservatively assumed to be $25 \%$ of the reference value. A bounding value of $R M=1$ is used as the weighting factor for the FRS "new" sludge to be stored in the WP. Assuming a spherical shape for the broken FRS pieces, an equivalent diameter with $A / M$ equal to $1500 \mathrm{~cm}^{2} \mathrm{U} / \mathrm{kg} \mathrm{U}$

(or $1.5 \mathrm{~cm}^{2} \mathrm{U} / \mathrm{g} \mathrm{U}$ ) would be:

$\frac{\mathrm{A}}{\mathrm{M}}=\frac{6}{\rho \mathrm{D}}$ or $\mathrm{D}=\frac{6}{\rho(\mathrm{A} / \mathrm{M})}=\frac{\underline{6}}{(19)(1.5)}=0.21 \mathrm{~cm}$ or $2100 \mu \mathrm{m}$

It is assumed that the pieces of broken fuel or available uranium metal generated from the FRS cleaning activity will have a smaller $A / M$ value than the effective $A / M$ value calculated from the most reactive lab sample. It is assumed the $A / M$ value can only be equal to or greater than the most reactive canister sludge sample by molecular corrosivity reduction rather than mechanical actions from the PCM process. Therefore, assuming spherical FRS particles, the broken uranium metal pieces would have to be smaller than $2100 \mu \mathrm{m}$ in diameter to possess a greater $\mathrm{A} / \mathrm{M}$ value which would increase the uranium/water corrosion reaction rate. It is not expected or assumed that uranium metal will fracture into a substantial number of pieces this small. Therefore, for the purpose of this document, it will be asssumed that the RM value for FRS-generated "new" sludge will have a value of 1 . 


$$
\text { HNF-SD-SNF-TI-047, Rev. } 0
$$

The RM values are determined from the following as-settled sludge type amounts (Makenas 1996a and Omberg 1996) with the Layer 3 RM. value determined from the weighted sludge types:

As-sttld Sldg U Amt (kg U) $\underline{A} / M_{r e f}\left(\mathrm{~cm}^{2} \mathrm{U} / \mathrm{kg} U\right) \times \mathrm{RM} \quad \underline{A\left(\mathrm{~cm}^{2} U\right)}$

\section{Layer 1}

Existing

WP sludge

$0.59 \times 10^{3} \quad 1500 \times 0.25$

$221 \times 10^{3}$

Layer 2

Floor siudge

from Equip.

Installation

$0.29 \times 10^{3}$

$1500 \times 0.25$

$109 \times 10^{3}$

Layer 3

Can. Sludge

$9.0 \times 10^{3}$

$1500 \times 0.63$

$8505 \times 10^{3}$

FRS Generated

"Chips"

$9.6 \times 10^{3}$

$1500 \times 1.0$

$14400 \times 10^{3}$

Total U

Stored in

Layer 3

$18.6 \times 10^{3} \mathrm{~kg} \mathrm{U} \quad 1500 \times \mathrm{RM}_{\text {Layer } 3} 22905 \times 10^{3} \mathrm{~cm}^{2} \mathrm{U}$

Therefore,

$$
\mathrm{RM}_{\text {Layer 3 }}=\frac{22905 \times 10^{3}}{18.6 \times 10^{3} \times 1500}=0.82
$$

Total U

Stored in WP $19.4 \times 10^{3} \mathrm{~kg} \mathrm{U}$

$23,235 \times 10^{3} \mathrm{~cm}^{2} \mathrm{U}$ 


\section{HNF-SD-SNF-TI-047, Rev. 0}

\section{Reaction Term}

The uranium/water reaction is exothermic. Heats of formation for $\mathrm{UO}_{2}$ and $\mathrm{H}_{2} \mathrm{O}$ (liq.) at $25{ }^{\circ} \mathrm{C}$ are used to calculate the heat of reaction for the uranium/water reaction as shown below:

$$
\begin{aligned}
& \mathrm{U}+\mathrm{O}_{2} \rightarrow \mathrm{UO}_{2} \quad \Delta \mathrm{H}_{\mathrm{f}}=-260 \mathrm{kcal} / \mathrm{mol} \mathrm{UO}_{2} \\
& 2\left(\mathrm{H}_{2} \mathrm{O}--\rightarrow 0.5 \mathrm{O}_{2}+\mathrm{H}_{2}\right) \quad \Delta \mathrm{H}_{\mathrm{f}}=2\left(+68 \mathrm{kcal} / \mathrm{mol} \mathrm{H}_{2} \mathrm{O}\right) \\
& \mathrm{U}+2 \mathrm{H}_{2} \mathrm{O}-\rightarrow \mathrm{UO}_{2}+\mathrm{H}_{2} \quad \Delta \mathrm{H}_{\mathrm{rmn}}=-124 \mathrm{kcal} / \mathrm{mol} \mathrm{U} \\
& \mathrm{H}_{\mathrm{rxm}}=124 \underset{\mathrm{mol} \mathrm{U}}{\mathrm{kcal}} \times \frac{\mathrm{mol} \mathrm{U}}{238 \mathrm{~g}} \times 1.163 \times 10^{-3} \frac{\mathrm{kW}-\mathrm{hr}}{\mathrm{kcal}} \times 1000 \frac{\mathrm{g}}{\mathrm{kg}} \\
& =0.61 \frac{\mathrm{kW}-\mathrm{hr}}{\mathrm{kg} \mathrm{U}}
\end{aligned}
$$

From kinetics :

$$
\begin{aligned}
& \mathrm{K}^{\mathrm{UKB}}=\left(7.43 \times 10^{-6}\right) \times 10^{(7.364-3016 / \mathrm{I})} \quad[=] \mathrm{kg} \mathrm{U} / \mathrm{cm}^{2} \mathrm{U}-\mathrm{hr} \\
& \mathrm{q}_{\mathrm{rxn}}=\begin{array}{lllllllll}
\mathrm{RM} & \mathrm{x} & \mathrm{K}^{\mathrm{Ukg}} & \mathrm{x} & \frac{\mathrm{A}}{\mathrm{M}} & \mathrm{x} & \mathrm{U}_{\text {Conc }} & \mathbf{x} & \mathrm{H}_{\mathrm{rxm}}
\end{array}
\end{aligned}
$$

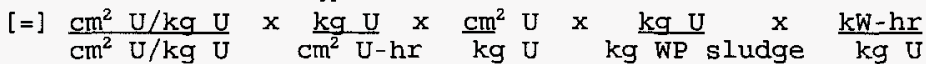

$$
\begin{aligned}
& {[=] \quad g^{\underline{k W}} \text { WP sludge }} \\
& =\mathrm{RM} \times \mathrm{U}_{\text {Conc }} \times 7.43 \times 10^{-6} \times 10^{(7.364-3016 / \mathrm{T})} \times 1500 \times 10.61 \\
& =\mathrm{RM} \times \mathrm{U}_{\mathrm{Conc}} \times 0.0068 \times 10^{(7.364-3016 / \mathrm{T})} \mathrm{kW} \\
& \text { kg WP sludge }
\end{aligned}
$$




\section{B. Radiolytic Decay}

The radioactive decay occuring in the reacted and unreacted uranium release heat. The average decay heat in the KE Basin is $0.073 \mathrm{~kW} / \mathrm{MT}$ of uranium (Willis 1995). The rate of radioactive decay heat in the $\mathrm{KE}$ Basin sludge is dependent on the amount of uranium within the sludge.

\section{Decay Term}

$$
\begin{aligned}
q_{\text {decay }} & =\frac{0.073 \mathrm{~kW}}{\mathrm{MTU}} \times \frac{\mathrm{kg} \mathrm{KE} \text { sludge }}{\mathrm{kg} \mathrm{U}} \times \frac{\mathrm{MT}}{1000 \mathrm{~kg}} \\
& =\frac{7.3 \times 10^{-5} \mathrm{KW}}{\mathrm{kg} \mathrm{U}} \times \mathrm{U}_{\text {cono }}
\end{aligned}
$$

For reacted fuel, the decay heat is actually less because soluble isotopes, such as cesium and strontium, when released from the fuel matrix by the reaction, dissolve into the pool water and are removed by the IXM's. Based on the WP and floor sludge characterization data, $60 \%$ of the decay heat in the fuel is still present (Makenas 1996). Thus, the remaining decay heat in reacted fuel is:

$q_{\text {rem.decay }}=(0.60) \times 7.3 \times 10^{-5}=4.4 \times 10^{-5} \quad \mathrm{~kg} \mathrm{KE} \mathrm{basin} \mathrm{sludge}$

\section{Heat Transfer in stored Sludge}

\section{A. Conductive Transfer}

Generated heat must be dissipated through the sludge layer in the WP and released into the surrounding environment. Heat transfer will be to the overlying water in the WP and through the concrete floor and side walls. The overlying water and concrete floor have the largest heat transfer area; however, since the concrete floor is adjacent to a thick layer of soil, for analytical simplicity, heat transfer will be assumed to occur only to the overlying water. 


\section{HNF-SD-SNE-TI-047, Rev. O}

The transfer of generated heat out of a thick sludge layer will be by conduction since the particles and water in the sludge mass will not freely circulate. At equilibrium, the heat from the corrosion reaction and the decay heat will equal the heat loss through the sludge layer. The sludge that is transferred to the WP will have irradiated uranium throughout. Approximating the situation with a one-dimensional model:

$$
\frac{\mathrm{d}^{2} \mathrm{~T}}{\mathrm{dx} \mathrm{x}^{2}}+\frac{\rho \mathrm{g}_{\mathrm{gen}}}{\mathrm{k}}=0
$$

with boundary conditions:

- assuming WP floor concrete acts as an insulator (very little heat being transferred to concrete and ground), therefore,

$$
\begin{aligned}
& \frac{d T}{d x}=0 \text { at } x=0 \text { at } x=L \text { (top of sludge/water interface) } \\
& \mathrm{dx}=\mathrm{T}_{\text {sludge botton }} \mathrm{T}=10^{\circ} \mathrm{C} \\
& \text { Where : } \quad q_{\text {gen }}=q_{\text {decay }}+q_{r m}=\text { heat generating terms, } \mathrm{kW} / \mathrm{kg} \\
& \mathrm{T}=\text { the sludge temperature in the } \mathrm{WP},{ }^{\circ} \mathrm{K} \\
& \mathbf{x}=\text { the vertical distance of the sludge in the WP, cm } \\
& \rho \quad=\text { density of sludge, } \mathrm{kg} / \mathrm{cm}^{3} \\
& \mathbf{k}=\text { thermal conductivity of the sludge mass, } \\
& \mathrm{kW} /{ }^{\circ} \mathrm{K}-\mathrm{cm} \text {. Over small temperature ranges } \mathrm{k} \text { is } \\
& \text { assumed constant. }
\end{aligned}
$$

\section{1) Thermal conductivity of sludge}

No measurements of thermal conductivity of the sludge are available. Existing sludge types are a mixture of sand, dirt, concrete, uranium oxide, uranium metal, and other components. New sludge generated by FRS activities will be uranium metal and uranium oxide. This will settle in the Weasel Pit. Settled sludge is generally 50\% water and 50\% particulate. 


\section{HNF-SD-SNF-TI-047, Rev. 0}

Thermal conductivities are found in Table IV. Appendix IV

"Introduction to Nuclear Engineering" by John R. LaMarsh and in Standard Handbook for Mechanical Engineers by Theodore

Baumeister, ed.

\begin{tabular}{|c|c|c|c|}
\hline & $\underline{K}$ & & $\mathrm{k}$ \\
\hline & $\left(\overline{\mathrm{BTU}}{ }^{\circ} \mathrm{F}-\mathrm{ft}\right)$ & & $\left(\mathrm{kW} /{ }^{\circ} \mathrm{C}-\mathrm{cm}\right)$ \\
\hline $\mathrm{U}_{\mathrm{met} a \mathrm{I}}$ & 14 & 2.4 & $\times 10^{-4}$ \\
\hline $\mathrm{UO}_{2}$ & 5 & 8.6 & $\times 10^{-5}$ \\
\hline Water & 0.34 & & $5.9 \times 10^{-}$ \\
\hline Concrete & 1.05 & & $1.8 \times 10^{-5}$ \\
\hline Sand & 0.19 & & $3.3 \times 10^{-6}$ \\
\hline
\end{tabular}

For conservatism, the thermal conductivity of the sludge will be based on an estimate of the non-metallic components. For heat transfer thru parallel paths, from Perry's 4th, pg 10-5.

$$
\begin{aligned}
& \left.\frac{1}{k_{\mathrm{mix}}}=\frac{(25 \% \text { Sand }}{\mathrm{k}_{\mathrm{sand}}}+\frac{(25 \% \text { Concrete }}{\mathrm{k}_{\text {concrete }}}+\frac{(50 \% \text { Water }}{\mathrm{k}_{\text {Water }}}\right)
\end{aligned}
$$

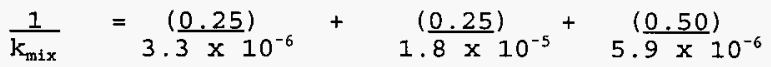

$$
\begin{aligned}
& k_{\mathrm{mix}}=5.7 \times 10^{-6} \mathrm{~kW} /{ }^{\circ} \mathrm{C}-\mathrm{cm} \\
& \approx \quad 6.0 \times 10^{-6} \mathrm{~kW} /{ }^{\circ} \mathrm{C}-\mathrm{Cm}
\end{aligned}
$$

From a less conservative viewpoint, sludge composed of only uranium compounds and water would have a higher thermal conductivity. For sludge composed of $50 \mathrm{v} / \mathrm{v}$ \% water, $25 \mathrm{v} / \mathrm{v}$ \% $\mathrm{UO}_{2}$, and $25 \mathrm{v} / \mathrm{v} \% \mathrm{U}$ metal:

$\frac{1}{k_{\operatorname{mix}}}=\frac{(50 \% \text { Water }}{5.9 \times 10^{-6}}+\frac{\left(25 \% \mathrm{UO}_{2}\right)}{8.6 \times 10^{-5}}+\frac{(25 \% \mathrm{U} \text { metal })}{2.4 \times 10^{-4}}$

$k_{\operatorname{mix}}=1.13 \times 10^{-5} \mathrm{~kW} /{ }^{\circ} \mathrm{C}-\mathrm{cm}$

Generally, the more conservative, former value $\left(\mathrm{k}_{\operatorname{mix}}=6.0 \times 10^{-6} \mathrm{~kW} /{ }^{\circ} \mathrm{C}-\mathrm{cm}\right)$ will be used in the heat transfer calculations. 


\section{FNF-SD-SNF-TI-047, Rev. 0}

\section{2) Temperature at the sludge/Water Interface}

The water in the WP will be free flowing with itself. In flow and out flow will be $400 \mathrm{gpm}$. This will keep the Weasel pit water temperature at the basin temperature at approximately $283 \mathrm{~K}\left(10^{\circ} \mathrm{C}\right)$.

The $400 \mathrm{gpm}$ circulation rate will carry away any reasonable quanitity for reaction and decay heat. For convective heat transfer:

$$
\mathrm{Q}=\mathrm{mC}_{\mathrm{p}} \Delta \mathrm{T}
$$

where: $Q=$ heat transferred, $k W$

$$
\begin{aligned}
& \mathrm{m}=\text { mass flow rate of heat transfer fluid, } \mathrm{kg} / \mathrm{hr} \\
& \mathrm{C}_{\mathrm{p}}=\text { heat capacity of water, } \mathrm{kW} /{ }^{\circ} \mathrm{C}-\mathrm{kg} \\
& \Delta \mathrm{T}=\text { temperature change of convective fluid }
\end{aligned}
$$

with,

$$
\begin{aligned}
\mathrm{m} & =400 \mathrm{gal} / \mathrm{min} \times 60 \mathrm{~min} / \mathrm{hr} \times \quad 8.34 \quad \# / \mathrm{gal} \times 0.454 \mathrm{~kg} / \# \\
& =91,000 \mathrm{~kg} / \mathrm{hr} \\
\mathrm{C}_{\mathrm{p}} & =1.0 \mathrm{BTU} / \mathrm{hr}-{ }^{0} \mathrm{~F}-\# \times 1.8 \Delta^{0} \mathrm{~F} / \Delta^{0} \mathrm{C} \times \mathrm{kW}-\mathrm{hr} / 3414 \mathrm{BTU} \times \# / 0.454 \mathrm{~kg} \\
& =1.2 \times 10^{-3} \mathrm{~kW} / \mathrm{kg}-{ }^{0} \mathrm{C}
\end{aligned}
$$

Therefore,

$\mathrm{Q} / \Delta \mathrm{T}=\mathrm{mC}_{\mathrm{p}}=91,000 \mathrm{~kg} / \mathrm{hr} \times 1.2 \times 10^{-3} \mathrm{~kW} / \mathrm{kg}-{ }^{\circ} \mathrm{C}=109 \mathrm{~kW} /{ }^{\circ} \mathrm{C}-\mathrm{hr}$ 


\section{3) Weasel Pit Sludge Depth}

Sludge will settle in the WP in an uneven manner. The heaviest, largest particle size sludge will settle close to the hydrocyclones. Lighter or smaller particles will distribute more. It will be assumed for this analysis active management by operations will evenly distribute sludge over the available area to minimize sludge depth.

The surface area available for heat transfer will be estimated as a planar area parallel to the wP floor. The floor area of the WP used for storing sludge covers approximately $16.2 \mathrm{~m}^{2}\left(174 \mathrm{ft}^{2}\right)$.

The expected "upper bound" height of the sludge in the WP has been estimated at about $1.8 \mathrm{~m}(6 \mathrm{ft})$. The average depth of the existing sludge is approximately $75 \mathrm{~cm}(2.5 \mathrm{ft})$.

The "upper bound" estimated height of $1.8 \mathrm{~m}(6 \mathrm{ft})$ of as-settled sludge includes $12 \mathrm{~m}^{3}\left(424 \mathrm{ft}^{3}\right)$ of sludge currently in the WP, $6.5 \mathrm{~m}^{3}$ (230 $\mathrm{ft}^{3}$ ) expected to be added during equipment installation, and approximately $7.4 \mathrm{~m}^{3}\left(260 \mathrm{ft}^{3}\right)$ of canister sludge with an estimated volume of $3.2 \mathrm{~m}^{3}\left(113 \mathrm{ft}^{3}\right)$ of FRSgenerated chips.

\section{4) Estimated sludge Temperature Profiles and Allowed Maximum Sludge Depth}

Refer to main text. 


\section{Hydrogen Gas Generation}

The $\mathrm{H}_{2}$ gas generation rate from the layered sludge mass is dependent on the effective or available uranium (for surface reaction) and the sludge temperature. A "lower bound" conservative estimate assumes the sludge is immediately deposited into the WP at the maximum stable sludge "bottom" temperature (58 $\left.{ }^{\circ} \mathrm{C}\right)$. The entire layered sludge mass is assumed to be at $58{ }^{\circ} \mathrm{C}$. Average values for the RM and uranium concentration are used for the entire sludge mass in the WP.

Therefore, the "lower bound" hydrogen gas generation rate is conservatively estimated to be:

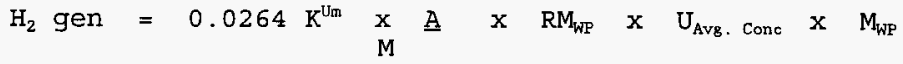
where:

$$
\begin{aligned}
& 0.0264 \mathrm{~K}^{\mathrm{Um}}(\mathrm{T}=331 \mathrm{~K})=0.0264\left(3.125 \times 10^{-5} \times 10^{(7.364-3016 / 331)}\right) \\
& =1.47 \times 10^{-8} \frac{\mathrm{Cfm} \mathrm{H}_{2}}{\mathrm{~cm}^{2} \mathrm{U}} \\
& \frac{\mathrm{A}}{\mathrm{M}}=1500 \frac{\mathrm{cm}^{2}}{\mathrm{~kg}} \mathrm{U} \\
& \mathrm{RM}_{\mathrm{WP} \text { Sludge }}=\frac{23235 \times 10^{3} \mathrm{~cm}^{2} \mathrm{U}}{19.4 \times 10^{3} \mathrm{~kg} \mathrm{U} \times 1500 \frac{\mathrm{cm}^{2} \mathrm{U}}{\mathrm{kg} \mathrm{U}}} \quad 0.80 \\
& \mathrm{U}_{\text {Avg. Conc }}=\frac{19.4 \times 10^{3} \mathrm{~kg} \mathrm{U}}{52.2 \times 10^{3} \mathrm{~kg} \mathrm{WP} \mathrm{sludge}}=0.37 \mathrm{~kg} \mathrm{U} / \mathrm{kg} \text { WP sludge } \\
& \rho_{\text {WP AVB }}=\frac{1.5(12+6.5)+2(7.4)+3(3.2)}{29.2}=1.8 \mathrm{~g} / \mathrm{cm}^{3} \\
& \mathrm{M}_{\text {WP Sludge }}=29.1 \mathrm{~m}^{3} \times \rho_{\mathrm{WP} \text { Avg }} \\
& =29.1 \mathrm{~m}^{3} \times 1.8 \underset{\mathrm{cm}^{3}}{\mathrm{~g}} \times 10^{6} \frac{\mathrm{cm}^{3}}{\mathrm{~m}^{3}} \times \frac{\mathrm{kg}}{10^{3}} \mathrm{~g} \\
& =52,380 \mathrm{~kg} \text { WP sludge }
\end{aligned}
$$


INF-SD-SNF-TI-047, Rev . O

Therefore,

$\mathrm{H}_{2}$ gen $\left(58^{\circ} \mathrm{C}\right)=1.47 \times 10^{-8} \times 1500 \times 0.80 \times 0.37 \times 52,380$

$=0.34 \mathrm{cfm} \mathrm{H}$

For the extreme case of a "runaway" or unstable condition, where the sludge generates more heat than it is able to release at the basin water temperature limit $\left(10^{\circ} \mathrm{C}\right)$, the water would reach its boiling temperature. Therefore, an "upper bound" conservative estimate assumes the sludge is immediately deposited into the WP at $100^{\circ} \mathrm{C}$. Using the same values as above, only with the sludge temperature at $100{ }^{\circ} \mathrm{C}$, the "upper bound" hydrogen generation rate is conservatively estimated to be:

$\mathrm{H}_{2}$ gen $\left(100^{\circ} \mathrm{C}\right)=3.6 \mathrm{cfm} \mathrm{H}$ 


\section{DISTRIBUTION SHEET}

\begin{tabular}{|c|c|c|c|c|c|}
\hline \multirow{2}{*}{$\begin{array}{l}\text { To } \\
\text { Distribution }\end{array}$} & \multirow{2}{*}{\multicolumn{3}{|c|}{$\begin{array}{l}\text { From } \\
\text { Facility Cleanup Projects }\end{array}$}} & \multicolumn{2}{|c|}{ Page 1 of 1} \\
\hline & & & & \multicolumn{2}{|c|}{ Date 21 February 1997} \\
\hline \multicolumn{4}{|l|}{ Project Title/Work Order } & \multicolumn{2}{|c|}{ EDT No. 620626} \\
\hline \multicolumn{4}{|c|}{$\begin{array}{l}\text { Heat Transfer Analysis of Sludge Storage in the K East Basin } \\
\text { Weasel Pit }\end{array}$} & ECN No. & \\
\hline Name & MSIN & $\begin{array}{l}\text { Text } \\
\text { With All } \\
\text { Attach. }\end{array}$ & Toxt Only & $\begin{array}{l}\text { Attach./ } \\
\text { Appendix } \\
\text { Only }\end{array}$ & $\begin{array}{c}\text { EOT/ECN } \\
\text { Only }\end{array}$ \\
\hline
\end{tabular}

\section{E. D. MacAlister}

P. G. Loscoe

$$
\text { S7-41 }
$$

$57-41$

$x$
$x$

Fluor Daniel Hanford, Inc.
E. W. Gerber
R3-11
$x$

Duke Engineering and Services Hanford, Inc.

C. J. Alderman

D. W. Bergmann

K. H. Bergsman

S. P. Burke

R. G. Cowan

C. Defigh-Price

J. R. Gregory

V. L. Hoefer

H. L. Johnson

J. M. Kurta

R. J. Lodwick

R. H. Meichle

T. D. Merk 1 ing

M. J. Packer (5)

T. R. Pauly

K. L. Pearce

A. L. Pitner

D. R. Precechtel

D. S. Takasumi

C. A. Thompson

D. J. Watson

M. J. Wiemers

Central Files

$\mathrm{K}$ Basin Project Files

SNF Project Files

SGN Eurisys Corporation

A. L. Pajunen

Los Alamos Technical Associates

D. E. Ball
R3-48

R3-86

R3-48

$\mathrm{X} 3-74$

R3-88

$\times 3-79$

$\times 3-72$

R3-11

$X 3-80$

$\times 3-74$

$\times 3-78$

$\times 3-79$

N1-24

R3-48

$\times 3-85$

R3-48

HO- 40

R3-48

$\times 3-85$

R3-85

$\times 3-79$

$\times 3-85$

A3-94

$\times 3-85$

$X 3-79$

R3-86

$x$

$x$ 